\title{
The Roles of University English Teachers in Malaysia
}

\author{
Latisha Asmaak Shafie \\ Language Studies Academy, Universiti Teknologi MARA, Malaysia \\ Email: ciklatisha@perlis.uitm.edu.my \\ Surina Nayan \\ Language Studies Academy, Universiti Teknologi MARA, Malaysia \\ Email: surinana@perlis.uitm.edu.my
}

\begin{abstract}
The roles of language teachers at higher institutions need to be re-defined as modern technologies, curriculum development, job market and education reform influence their roles. As the Internet acts as the guru for the learners and the information is at everyone's fingertips, the roles of traditional gurus are expected to be changed and transformed.The purpose of this study is to study the changing roles of university English teachers from being language teachers to being learners, facilitators and researchers and to identify these new roles. In order to understand the role transformation whether it is feasible and realistic, it is imperative to study the many roles of university English teachers defined by the teachers and the university administrators. The findings suggest that by understanding the many roles of university English teachers, university English teachers are able to embrace their new roles.
\end{abstract}

Index Terms - university English teachers, teachers' roles, role transformation

\section{INTRODUCTION}

Due to the changes of university English teaching in terms of curriculum goals, modern technologies and market demands, it is expected that English teachers should transform their roles from being traditional language teachers to being trainers, organizers, promoters, learners and researchers. Is the role transformation feasible and realistic? The researchers of this paper expect to find answers for these questions with the objectives of helping university language teachers to enhance self-understanding and assume complex roles so as to implement effective teaching to embrace the new responsibilities of language teachers at higher institutions. This study analyses the views of university English teachers defined by the teachers and the university administrators.

\section{LITERATURE REVIEW}

The roles of university teachers are complicated to define as there are many classifications of a university lecturer's role.According to Braskamp \& Ory's four dimensional classification (1994), the lecturers' role are within the parameters of teaching, research and creativity, practice \& professional service and citizenship. Harden R M and Crosby J R (2000) identify twelve roles of lecturer which are grouped into six categories: the information provider, the rolemodel, the facilitator, the assessor, the planner and the resource developer. Not all the teachers aware of all these roles as some of the teachers would play all these roles while others played less roles. Thus trainings need to be enforced to teachers so they utilize these twelve roles framework.

Tamblyn (2002) identifies seven qualities of successful teachers in which the first three qualities are the skills of successful teachers such in subject competency, creativity, flexibility in using expertise and motivation. While the remaining seven qualities are personality and attitudes of the teachers such as willingness to take risks and make mistakes, respect for learners, caring, warmth, love and sense of humor, pride in the profession and a willingness to go the extra mile.

Borg (2003) believes that teaching and instructions given in classrooms are influenced by the teachers' knowledge, beliefs and opinions. This finding is supported by Lynch (1990) states teacher's belief about language education and their experiences in learning and teaching the language dictate their teaching roles. Teachers' actions in the classrooms are determined by their beliefs and their beliefs are determined by their actions which influence their roles in the class. According to Clark and Peterson (1986), there are three parts of cognitive processes such as teacher planning, thoughts and decisions and theories and beliefs. Theories and beliefs of the teachers influence their roles. In order to know the roles language teachers play in their classrooms, it is imperative to understand about their cognitive processes.

In online learning, Koistinen(2002) describes teacher's role in network is more to a coach, a personal trainer and a student. This is when sometimes the learners become the teachers. Meanwhile Goodyear, Salmon, Spector, Steeples \& Tickner (2001) define the roles of a competent online teacher as technologist, designer, administrator, process facilitator, counselor, assessor and researcher .Malcolm J. Benson and Dong Mei (2007) in a study analyzing roles of language 
teachers in China found two dimensions which form four quadrants associated with the effectiveness of English teachers in China. English teachers in China distributed roles of current English teachers based on these characteristics of each quadrant. The complicated and conflicting roles of English teachers in China are caused by the demands of schools, the government, the market and the students. They suggest that any qualified college English teachers need to realize the existence of such contradictions so they know how to play their roles accordingly so dialectical way of thinking is imperative .

Hill and Brindley (2005) indicate that the reasons why teachers undertake research are able to reflect upon and improving their practice rank. When asked about being a teacher and a writer, English teachers and researchers simultaneously able to reflect on their professional growth and learning, to understand their teaching contexts and the students' learning, identify and overcome obstacles, new ways of thinking and researching their own practice.

\section{RESEARCH OBJECTIVES}

The research was carried out to investigate the following research objectives:

1. To determine the language teachers' perception of their role based on their years of service at the university

2. To determine the administrators' perception of the language teachers' role

\section{METHODOLOGY}

The questionnaire was administered to the 30 language teachers and administrators .A total of 30 respondents consisted of 23 English language teachers and 7 administrators who were academic coordinators for their faculties. Among the language teachers, 20 were female and 3 male, and their teaching experiences ranges from one year to more than 20 years. The majority of them possess a master's degree. The questionnaire was adapted from the twelve roles of teachers suggested by Harden R M and Crosby J R (2000). The respondents were asked to choose the most frequent roles of a language teacher from a list of roles which was adapted from the twelve roles of teachers suggested by Harden R M and Crosby J R (2000). The questions were related to the following three dimensions which include the six aspects of the teacher expectations; cognitive role dimension-relationships with the students and personality, cognitive role dimension-knowledge of subject and presentation of knowledge; professional role dimension-professional leadership and quality of memberships.

\section{FINDINGS AND DISCUSSIONS}

\section{A. The Language Teachers' Perception of their Roles}

Language teachers who have less than 5 years of teaching emphasized the importance of being a learning facilitator as the most important role of being a language teacher. The second role is being a role model in classroom setting . The third important role is being an information provider as a teacher in classroom setting. In this role, a language teacher is responsible in being able to teach grammar and the rules of the language. The fourth role is curriculum evaluator in evaluating the curriculum. The fifth important role is as a course organizer being responsible in implementing the curriculum.

TABLE 1

LANGUAGE TEACHERS LESS THAN 5 YEARS TEACHING EXPERIENCES

\begin{tabular}{|c|c|c|}
\hline Category & Role & Rank \\
\hline Facilitator & Learning Facilitator & 2 \\
\hline Role model & $\begin{array}{c}\text { On-the-job role model } \\
\text { Role model in the teaching setting }\end{array}$ \\
\hline Information provider & Teacher in classroom & 3 \\
\hline Planner & Curriculum Evaluator & 4 \\
\hline Planner & Course organizer & 5 \\
\hline
\end{tabular}

University language teachers who have 5 to 9 years of teaching chose the role of being a teacher in classroom under the category of information provider is the most important role. The second role is being a role model in the teaching setting. The third role is being a mentor to students and the fourth role is learning facilitator in facilitating students' learning. The fifth role is resource developer in developing learning materials. This role is influenced by the increasing experiences and exposure these teachers have which enable them to be more confident in sharing their experiences through learning materials. 
TABLE 2

LANGUAGE TEACHERS 5-9 YEARS TEACHING EXPERIENCES

\begin{tabular}{|c|c|c|}
\hline Category & Role & Rank \\
\hline Information provider & Teacher in classroom & 2 \\
\hline Role model & Role model in the teaching setting & 3 \\
\hline Facilitator & Mentor & 4 \\
\hline Facilitator & Learning facilitator & 5 \\
\hline Resource developer & $\begin{array}{c}\text { Study guides and learning resources } \\
\text { materials developer }\end{array}$ & \\
\hline
\end{tabular}

Language teachers who have 10 to 15 years of teaching chose information provider as teacher in classroom setting as the most important role. The second role is being a learning facilitator and the third role is being a role model in the teaching setting. The fourth role is examiner in planning and participating in formal examinations of students. The experiences they have as university language teachers enable them to be given the responsibility of constructing examination questions. The fifth role is being a course organizer.

TABLE 3

LANGUAGE TEACHERS 10-15 YEARS TEACHING EXPERIENCES

\begin{tabular}{|c|c|c|}
\hline Category & Role & Rank \\
\hline Information provider & Teacher in classroom & 2 \\
\hline Facilitator & Learning facilitator & 3 \\
\hline Role model & Role model in the teaching setting & 4 \\
\hline Examiner & Planning or participating in formal & 5 \\
\hline Planner & Couminations & 5 \\
\hline
\end{tabular}

Language teachers who have 16-20 years of teaching chose being a planner as the most important role. The second role is being a learning facilitator. The third role is course organizer and the fourth role is examiner. This is influenced by the teachers' years of service at the university. They are confident with their roles .The fifth role is being a role model in outside classroom setting.

TABLE 4

LANGUAGE TEACHERS 16-20 YEARS TEACHING EXPERIENCES

\begin{tabular}{|c|c|c|}
\hline \multicolumn{2}{|c|}{ LANGUAGE TEACHERS 16-20 YEARS TEACHING EXPERIENCES } & Rank \\
\hline Category & Role & 1 \\
\hline Planner & Curriculum planner & 3 \\
\hline Facilitator & Course organizer & 4 \\
\hline Planner & Curriculum Evaluator & 5 \\
\hline Examiner & Role model outside classroom settings & \\
\hline Role model & &
\end{tabular}

Language teachers who have more than 20 years chose the role of being a learning facilitator as the most important role. The second role is being a resource developer in producing study guides and learning resources materials. The third role is information provider in being teacher in classroom setting. The fourth role is curriculum planner and the fifth role is examiner.

TABLE 5

LANGUAGE TEACHERS WITH MORE THAN 20 YEARS OF TEACHING EXPERIENCES

\begin{tabular}{|c|c|c|}
\hline LANGUAGE TEACHERS WITH MORE THAN 20 YEARS OF TEACHING EXPERIENCES \\
\hline Category & Role & Rank \\
\hline Facilitator & Learning Facilitator & 2 \\
\hline Resource developer & $\begin{array}{c}\text { Study guides and learning resources materials } \\
\text { developer }\end{array}$ & 3 \\
\hline Information provider & Teacher in classroom & 4 \\
\hline Planner & Curriculum planner & 5 \\
\hline Examiner & $\begin{array}{c}\text { Planning or participating in formal } \\
\text { examinations }\end{array}$ & \\
\hline
\end{tabular}

In conclusion, language teachers listed facilitator, information provider, instructor of language, life-long learner, rolemodel, planner, examiner, trainer, resource developer and organizer.

\section{B. The Administrators' Perception of the Language Teachers' Role}

Meanwhile the administrators believed being an information provider as being a teacher in a classroom for a language teacher as being the most important role. This is because for the administrators, language teachers' role is to teach the language to the learners. The second role is being a resource developer in producing study guides and learning resources. The third role of a language teacher is being a learning facilitator. The fourth role is being a planner in curriculum planner and the fifth role is a role model in teaching setting. 
TABLE 6

ADMINISTRATORS

\begin{tabular}{|c|c|c|}
\hline Category & Role & Rank \\
\hline Information provider & Teacher in classroom & 1 \\
\hline Resource developer & $\begin{array}{c}\text { Study guides and learning resources materials } \\
\text { developer }\end{array}$ & 2 \\
\hline Facilitator & Learning facilitator & 3 \\
\hline Planner & Curriculum planner & 4 \\
\hline Role Model & Role model in the teaching setting & 5 \\
\hline
\end{tabular}

\section{IMPLICATIONS}

This study shed light on how university language teachers continuously play different roles in their careers as university language teachers. In addition, their roles change as their teaching experiences increase. The study provides university language teachers with a valuable insight of their own teaching practices and how the administrators expect them to play which roles. In return, the administrators are more aware of the roles played by the university language teachers. Therefore, by obtaining information on language teachers' perception about their roles in the classrooms enable these practitioners to be more aware of their practices and their roles in the class. Thus, enabling them to be more effective practitioners.

\section{REFERENCES}

[1] Borg,S.(2003).Review article-Teacher cognition in language teaching: A review of research on what language teachers think, know, believe, and do. Language Teaching, 36,81-109.

[2] Braskamp, L. A., \& Ory, J. C. (1994). Assessing faculty work: Enhancing individual and instructional practice. San Francisco: Jossey-Bass.

[3] Clark, C. M. \& Peterson, P. L. (1986). Teachers' thought processes. In M. C. Wittrock (Ed.), Handbook of research on Teaching. (pp. 255 - 296). New York: Simon and Schuster Macmillan.

[4] Goodyear, P., Salmon, G., Spector, J. M., Steeples, C. \& Tickner, S. (2001). Competencies for online teaching: A special report. Educational Technology Research and Development, 49(1), 65-72.

[5] Harden, R. M and Crosby, J R (2000).AMEE Education Guide No 20: The good teacher is more than a lecturer - the twelve roles of the teacher. Medical Teacher, 22(4): 334-347.

[6] Koistinen, K. (2002).Towards Virtual Academy - Teacher's Changing Role. Retrieved 10 december 2008 from http://www.fig.net/pub/fig_2002/Ts2-4/TS2_4_koistinen.pdf

[7] Lynch,T.(1990). Researching Teachers: Behavior and Belief in Research in the Language Classroom: ELT Documents 133 edited by Brumfit,C. \& Mitchell,R.H. Modern English Publications in association with the British Council.

[8] Malcolm J. Benson and Dong Mei.(2007). Analysis of the Role of Chinese English Teachers in higher education institutions. Retrieved December 10,2009 from http://www.shudo-gakujyutsu.net/magazine/pdf/hum/jin48-2PDF/jin48-2-01\%20Benson.pdf

[9] Tamblyn,P.(2000). Qualities of success: lessons from a teacher career. Education Canada,40(1),16-19.

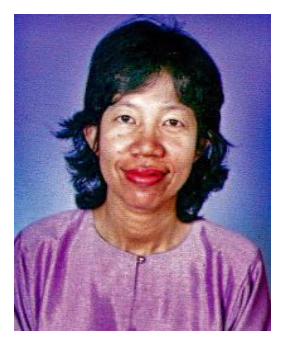

Latisha Asmaak Shafie obtained her Master in Instructional Technology from Universiti Malaya, Malaysia in 2004 and Bachelor in Education specializing in Teaching English as a Second Language from UKM, Malaysia in 1993.

She is a Senior Lecturer at the Academy of Language Studies, Universiti Teknologi MARA in Perlis. She has been teaching at Universiti Teknologi MARA since 1997.Her research interest includes teaching and learning English as a second language, digital learners and adult learners. She has written books, journals and presented many papers in education, teaching English in second language and digital technologies.

Ms Latisha is a member of ASIA TEFL.

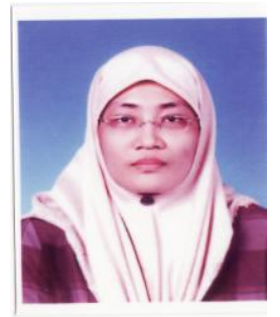

Surina Nayan obtained her Master in Linguistics and English Language Studies from Universiti Sains Malaysia in 2002, Post Graduate Diploma in TESL from Institut Teknologi MARA in 1996, Bachelor Science in Marketing from Oklahoma State University, U.S.A. in 1994 and Diploma in Banking from Institut Teknologi MARA in 1991.

She is a Senior Lecturer at the Academy of Language Studies, Universiti Teknologi MARA in Perlis. She has been teaching English for the past 13 years. Besides writing manuals and books collaboratively in the field of English Language Studies, she has also been involved in translating and editing work in various subjects. Her areas of interests are in the field of Business English, language learning and teaching, English for Specific purposes.

Ms Surina is a member of ASIA TEFL. 